\title{
Forebrain development in the Inpp5e ciliary mouse mutant is severely disrupted
}

\author{
T Theil $^{1^{*},}$ K Hasenpusch-Theil ${ }^{1}$, D Magnani ${ }^{1}$, S Gayral ${ }^{2}$, S Schurmans $^{2}$ \\ From First International Cilia in Development and Disease Scientific Conference (2012) \\ London, UK. 16-18 May 2012
}

Ciliopathies are an emerging group of related genetic disorders caused by defects in the function and/or structure of primary cilia, antenna like extensions protruding from the cell surface with important functions in signalling and sensory perception. Ciliopathies are characterized by pleiotropic clinical features and almost every organ in the body can be affected. Notably, many ciliopathy patients display important neurological features, most commonly mental retardation (MR), however, little is known about the pathogenesis underlying MR. Mutations in human INPP5E have been identified in MORM syndrome and Joubert syndrome (JS). JS is a genetically and phenotypically heterogeneous syndrome which can lead to MR and can also be associated with autism spectrum disorder. Here, we present the analyses of forebrain development in the Inpp5e ciliary mouse mutant. We show that in newborn Inpp5e mutants the corpus callosum is hypoplastic, consistent with callosal malformations often observed in ciliopathy patients. Also, the thalamocortical tract shows severe pathfinding defects. Many thalamocortical axons (TCAs) take an abnormal trajectory into the cortex while other TCAs are deflected ventrally towards the amygdala. In addition, while all hippocampal fields are specified, hippocampal size is severely reduced coinciding with a downregulation of $\mathrm{Wnt} / \beta$ catenin signalling during patterning stages. Finally, the cerebral cortex is extremely thin at caudal levels and exhibits cortical heterotopias with a local outgrowth of cortical tissue. Taken together, these findings indicate severe forebrain malformations in Inpp5e mutants offering a rare opportunity to study the pathogenesis of MR in a JS mouse model.

\section{Author details}

${ }^{1}$ University of Edinburgh, UK. ${ }^{2}$ Université de Liège, Belgium.

* Correspondence: thomas.theil@ed.ac.uk

'University of Edinburgh, UK

Full list of author information is available at the end of the article
Published: 16 November 2012

doi:10.1186/2046-2530-1-S1-P106

Cite this article as: Theil et al.: Forebrain development in the Inpp5e ciliary mouse mutant is severely disrupted. Cilia 2012 1(Suppl 1):P106.
Submit your next manuscript to BioMed Central and take full advantage of:

- Convenient online submission

- Thorough peer review

- No space constraints or color figure charges

- Immediate publication on acceptance

- Inclusion in PubMed, CAS, Scopus and Google Scholar

- Research which is freely available for redistribution

\section{() Biomed Central}

C Biomed Central

C 2012 Theil et al; licensee BioMed Central Ltd. This is an Open Access article distributed under the terms of the Creative Commons Attribution License (http://creativecommons.org/licenses/by/2.0), which permits unrestricted use, distribution, and reproduction in any medium, provided the original work is properly cited. 